\title{
DARIA ZABOREK
}

Uniwersytet Mikołaja Kopernika w Toruniu

daria.zaborek7@wp.pl

\section{KRZYSZTOF CZARNECKI}

Państwowa Wyższa Szkoła Zawodowa we Włocławku

krzysztof.czarnecki@pwsz.wloclawek.pl

\section{Podatki lokalne jako źródło}

\section{dochodów samorządu gminnego.}

\section{Analiza podatku od nieruchomości, podatku rolnego i leśnego $\mathrm{w}$ gminie \\ Lidzbark w latach 2010-2015}

Local taxes as a source of revenue of the local self-government. Analysis of a property tax, an agricultural and forest tax on the example of gmina Lidzbark in 2010-2015

Streszczenie. Zgodnie z art. 167 Konstytucji RP dochodami jednostek samorządu terytorialnego są ich dochody własne, subwencje ogólne oraz dotacje celowe. Dochody własne gmin obejmują w szczególności podatki i opłaty lokalne, w tym podatki, które można określić wspólnym mianem podatków gruntowych. Są to: podatek od nieruchomości, podatek rolny oraz podatek leśny. Gminy, dysponujące 
ograniczonym władztwem podatkowym, mogą w ustawowym zakresie kształtować niektóre elementy konstrukcyjne wymienionych podatków, głównie poprzez ustalanie obowiązujących w danym roku stawek. W artykule przedstawione zostały podatki gruntowe jako źródło dochodów gminy Lidzbark w latach 20102015.

Słowa kluczowe: samorząd terytorialny; podatek od nieruchomości; podatek rolny; podatek leśny; podatki gruntowe.

Abstract. According to Art. 167 of Polish Constitution, there are three main sources of local self-governments revenues: an own income, subsidies and grants. The own income of local communes (gminy) consists of local taxes and fees, including taxes which may also be collectively called "land taxes". Those taxes include a property tax, an agricultural tax and a forest tax. The authorities of local self-governments are entitled to decide on some aspects of local taxes, especially they are able to establish tax rates. The article presents land taxes as a source of revenue of gmina Lidzbark in the years 2010-2015.

Keywords: local self-government; property tax; agricultural tax; forest tax; land taxes.

\section{Wprowadzenie}

Podział dochodów publicznych między państwo a jednostki samorządu terytorialnego jest konsekwencją podziału zadań publicznych między organy administracji rządowej a samorządy wszystkich szczebli ${ }^{1}$. Stanowi wypełnienie nakazu wyrażonego w art. 167 ust. 1 Konstytucji $\mathrm{RP}^{2}$ oraz w art. 9 Europejskiej Karty Samorządu Lokalnego ${ }^{3}$. Podatki gruntowe -

1 A. Niezgoda, [w:] A. Hanusz, A. Niezgoda, P. Czerski, Dochody budżetu jednostek samorzqdu terytorialnego, Warszawa 2009, s. 15.

2 „Jednostkom samorządu terytorialnego zapewnia się udział w dochodach publicznych odpowiednio do przypadających im zadań”, Konstytucja Rzeczypospolitej Polskiej z dnia 2 kwietnia 1997 r. (Dz.U. Nr 78, poz. 483 ze zm.).

3 „Społeczności lokalne mają prawo, w ramach narodowej polityki gospodarczej, do posiadania własnych wystarczających zasobów finansowych, którymi mogą swobodnie dysponować w ramach wykonywania swych uprawnień” (ust. 1); „Przynajmniej część zasobów finansowych społeczności lokalnych powinna pochodzić z opłat i podatków lokalnych, których wysokość społeczności te mają prawo ustalać, w zakresie określonym ustawą" (ust. 3). Europejska Karta Samorządu Lokalnego sporządzona 
podatek od nieruchomości, podatek rolny oraz leśny - należą do kategorii podatków lokalnych, z których wpływy stanowią wyłączny dochód samorządu gminnego (dochody własne) ${ }^{4}$. Dysponując władztwem podatkowym, w ustawowo zakreślonych granicach, rady gmin mają możliwość kształtowania wysokości stawek tych podatków oraz wprowadzania zwolnień o charakterze przedmiotowym, innych niż wymienione wprost w ustawie ${ }^{5}$. Sposób, w jaki organ stanowiący gminy zdecyduje się z tych uprawnień skorzystać, zależy od polityki budżetowej danego samorządu. Jest ona determinowana ogólną kondycją finansową j.s.t., możliwościami pozyskiwania dochodów z innych źródeł, stopniem rozwoju gospodarczego gminy, lokalnymi potrzebami itp. W przypadku podatku od nieruchomości kształtowanie stawek podatkowych oraz wprowadzanie zwolnień przedmio-

w Strasburgu dnia 15 października 1985 r., ratyfikowana przez Polskę dnia 26 kwietnia 1993 r. (Dz.U. z 1994 r. Nr 124, poz. 607 ze sprost.).

4 Należy pamiętać, że w przypadku podatku od nieruchomości przedmiot opodatkowania obejmuje nie tylko grunty, ale także budynki lub ich części oraz budowle lub ich części, związane z prowadzeniem działalności gospodarczej - art. 2 ust. 1 pkt 1-3 ustawy z dnia 12 stycznia 1991 r. o podatkach i opłatach lokalnych (tekst jedn. Dz.U. z 2017 r., poz. 1785 ze zm.). Charakterystyczną cechą podatków, które można określić wspólnym mianem ,gruntowych”, jest to, iż podstawę opodatkowania stanowi w ich przypadku powierzchnia danej nieruchomości (wyrażania $\mathrm{w} \mathrm{m}^{2}$, ha, ha przeliczeniowych). O tym, który z podatków gruntowych należy zastosować celem opodatkowania danej nieruchomości, decydują informacje zawarte w ewidencji gruntów i budynków, dlatego też aktualność informacji zwartych w ewidencji odgrywa istotną rolę dla finansów gminy (zob. szerzej: A Potocki, Zmiany informacji w ewidencji gruntów i budynków a proces wymiaru podatku od nieruchomości, rolnego i leśnego, „Prawo Budżetowe Państwa i Samorządu” 2016, nr 3, DOI: http://dx.doi.org/10.12775/PBPS.2016.019). Alternatywną konstrukcję opodatkowania nieruchomości gruntowych (i budynkowych) stanowią daniny, w których za podstawę opodatkowania przyjmuje się wartość nieruchomości. Przykładem takiego podatku jest dyskutowany w Polsce od wielu lat podatek katastralny. Zob. szerzej: J. Ciak, B. Wąsewicz, Kataster jako warunek reformy systemu opodatkowania nieruchomości w Polsce, „Prawo Budżetowe Państwa i Samorządu” 2014, nr 4, DOI: http://dx.doi.org/10.12775/PBPS.2014.035 oraz tychże Oczekiwany model katastru nieruchomości w Polsce, „Prawo Budżetowe Państwa i Samorządu” 2015, nr 1, DOI: http://dx.doi.org/10.12775/PBPS.2015.002.

5 Przyznanie samorządom części władztwa podatkowego wykonywanego uprzednio przez organy administracji centralnej (rząd) jest właśnie rezultatem rozdziału zadań między państwo a j.s.t. i przekazania samorządom wpływów z niektórych podatków jako ich dochodów własnych. Zob. szerzej E. Kornberger-Sokołowska, Decentralizacja finansów publicznych a samodzielność finansowa jednostek samorzq̨du terytorialnego, Warszawa 2001, s. 83. 
towych można uznać za instrument wspierający rozwój gospodarczy gminy ${ }^{6}$. Pamiętać jednak należy, że preferencje podatkowe dla przedsiębiorców, także w zakresie podatków lokalnych, stanowią formę pomocy publicznej, w związku z czym muszą pozostawać w zgodności z przepisami prawa krajowego i europejskiego dotyczącymi tej materii ${ }^{7}$.

Znaczenie i wydajność poszczególnych źródeł dochodów własnych, w tym badanych podatków gruntowych, wykazuje istotne zróżnicowanie w zależności od charakteru gminy (wiejska, miejsko-wiejska, miejska), warunków geograficznych, sposobu zagospodarowania terenu i innych. Dochody z podatku rolnego, mające istotne znaczenie w gminie wiejskiej, typowo rolniczej, charakteryzującej się występowaniem dobrych gleb i korzystnych warunków uprawy, będą odgrywały marginalną rolę lub nie wystąpią w ogóle na obszarach wysoko zurbanizowanych gmin miejskich. W zakresie podatku od nieruchomości korzystniejsza będzie sytuacja gminy, na terenie której znajdą się duże zakłady produkcyjne, kompleksy magazynowe czy centra logistyczne w porównaniu z gminą, w której liczba podmiotów gospodarczych jest niewielka, zaś grunty i budynki związane z prowadzeniem działalności gospodarczej zajmują małą powierzchnię. Podobnych zależności można by doszukiwać się w odniesieniu do większości pozostałych podatków i opłat lokalnych.

Celem artykułu jest ustalenie znaczenia dochodów pochodzących z podatków gruntowych (rolnego, leśnego i od nieruchomości) dla budżetu Lidzbarka, gminy miejsko-wiejskiej, położonej w północno-wschodniej Polsce, w województwie warmińsko-mazurskim. Przedział czasowy wybrany na potrzeby niniejszego opracowania obejmuje lata 2010-2015. W przekonaniu autorów analiza taka może stać się przyczynkiem do przeprowadzenia badania efektywności i znaczenia określonych źródeł podatkowych w szerszej skali i wyprowadzenia na tej podstawie bardziej uogólnionych wniosków.

\footnotetext{
6 Zob. szerzej M. Cilak, Instrumenty wspierania rozwoju gospodarczego stosowane przez samorzqd terytorialny. Problematyka prawnofinansowa, Toruń 2013, s. 107 i n.

A. Borodo, Samorzqd terytorialny. System prawnofinansowy, Warszawa 2008, s. 99.
} 


\section{Ogólna charakterystyka gminy Lidzbark}

Gmina Lidzbark jest gminą miejsko-wiejską, położoną w południowo-zachodniej części województwa warmińsko-mazurskiego, w powiecie działdowskim. W jej skład wchodzą 24 sołectwa oraz miasto Lidzbark, które jest siedzibą gminy. Powierzchnia gminy liczy 255 km² (25 488 ha), zaś liczba mieszkańców w 2015 r. wynosiła 14444 osoby. Obszar gminy stanowią głownie tereny rolnicze i leśne. Użytki rolne na terenie gminy zajmowały w 2014 r. 11495 ha, zaś grunty leśne w roku 2015 - 12388 ha ${ }^{8}$.

Głównym kierunkiem, w którym rozwija się gospodarka gminy Lidzbark, jest turystyka. Położenie gminy na terenie dwóch parków krajobrazowych w otoczeniu licznych jezior sprawia, że jest to obszar atrakcyjny turystycznie. Znajdują się tu liczne ośrodki wczasowe i gospodarstwa agroturystyczne ${ }^{9}$. Istotną rolę odgrywa też rolnictwo i przetwórstwo drewna. W gminie występują gospodarstwa indywidualne i zespołowe. Większość z nich prowadzi produkcję wielokierunkową, bez określonej specjalizacji. Uprawiane są zboża, rzepak, ziemniaki oraz buraki cukrowe, prowadzona jest hodowla bydła mlecznego i trzody chlewnej. Przemysł jest słabo rozwinięty, przeważa sektor usługowo-handlowy. Większość podmiotów gospodarczych to mikro- i mali przedsiębiorcy ${ }^{10}$.

Stopa bezrobocia w gminie w 2015 r. wynosiła 24,3\% i była wyższa o ok. 10 punktów procentowych od średniej w województwie warmińskomazurskim. Bez pracy pozostawało 30,8\% kobiet oraz 18,7\% mężczyzn ${ }^{11}$.

Dochody budżetu gminy Lidzbark w 2015 r. kształtowały się na poziomie $43 \mathrm{mln} \mathrm{zł}$, co w porównaniu z rokiem poprzednim oznaczało wzrost o 5,4\%. Spośród podatkowych dochodów własnych, największych wpływów do budżetu dostarczały podatki lokalne: od nieruchomości, rolny i leśny. Szczegółowa struktura dochodów z tych źródeł przedsta-

\footnotetext{
8 Zgodnie z danymi Głównego Urzędu Statystycznego, https://bdl.stat.gov.pl/BDL/dane/ teryt/kategoria/3117 (dostęp: 10.11.2017 r.).

9 Encyklopedia Warmii i Mazur, http://encyklopedia.warmia.mazury.pl/index.php/ Lidzbark_(gmina_miejsko-wiejska)\#Gospodarka (dostęp: 10.11.2017 r.).

10 Według danych GUS, https://bdl.stat.gov.pl/BDL/dane/teryt/kategoria/3117 (dostęp: 10.11.2017 r.).

11 Tamże.
} 
wiona zostanie w dalszych częściach opracowania. Pewną rolę odgrywały dochody majątkowe, które w roku 2015 wynosiły nieco ponad 1 mln zł.

Wydatki gminy w badanym okresie cechowały się stabilnością. Najwyższa kwota wykonanych wydatków wyniosła ponad 46 mln zł (2010 r.). W kolejnych latach wydatki były niższe i kształtowały się w granicach 40 mln zł (41,4 mln zł w 2015 r.).

Tabela 1. Wydatki budżetu gminy Lidzbark w latach 2010-2015 (kwoty wykonane).

\begin{tabular}{|c|c|c|c|}
\hline Rok & Wydatki ogółem & Wydatki bieżące & Wydatki majątkowe \\
\hline 2010 & $46471266,15 \mathrm{zł}$ & $30229994,65 \mathrm{zł}$ & $16241271,50 \mathrm{zł}$ \\
\hline 2011 & $36386476,65 \mathrm{zł}$ & $32632994,26 \mathrm{zł}$ & $3753482,39 \mathrm{zł}$ \\
\hline 2012 & $38969468,59 \mathrm{zł}$ & $34955192,63 \mathrm{zł}$ & $4014275,96 \mathrm{zł}$ \\
\hline 2013 & $40456698,82 \mathrm{zł}$ & $35021684,33 \mathrm{zł}$ & $5435014,49 \mathrm{zł}$ \\
\hline 2014 & $39665205,51 \mathrm{zł}$ & $34704169,81 \mathrm{zł}$ & $4961035,70 \mathrm{zł}$ \\
\hline 2015 & $41363805,52 \mathrm{zł}$ & $36238967,21 \mathrm{zł}$ & $5124838,31 \mathrm{zł}$ \\
\hline
\end{tabular}

Źródło: Opracowanie własne na podstawie sprawozdań z wykonania budżetu gminy Lidzbark z lat 2010-2015 $5^{12}$.

Największa część wydatków (38,2\%) została przeznaczona na oświatę i wychowanie oraz na pomoc społeczną (23,3\%).

12 Zarządzenie Nr 20/11 Burmistrza Lidzbarka z dnia 29 marca 2011 r. w sprawie przyjęcia sprawozdania z wykonania budżetu gminy Lidzbark za 2010 rok (Dz.Urz. Woj. Warmińsko-Mazurskiego z 2011 r., Nr 178, poz. 2965); Zarządzenie Nr 15/12 Burmistrza Lidzbarka z dnia 23 marca 2012 r. w sprawie przyjęcia sprawozdania z wykonania budżetu gminy Lidzbark za 2011 rok (Dz.Urz. Woj. Warmińsko-Mazurskiego z 2012 r., poz. 2010); Zarządzenie Nr 17/13 Burmistrza Lidzbarka z dnia 21 marca 2013 r. w sprawie przyjęcia sprawozdania z wykonania budżetu gminy Lidzbark za 2012 rok (Dz. Urz. Woj. Warmińsko-Mazurskiego z 2013 r., poz. 1819); Zarządzenie Nr 11/14 Burmistrza Lidzbarka z dnia 25 marca 2014 r. w sprawie przyjęcia sprawozdania z wykonania budżetu gminy Lidzbark za 2013 rok (Dz.Urz. Woj. Warmińsko-Mazurskiego z 2014 r., poz. 1951); Zarządzenie Nr 36/15 Burmistrza Lidzbarka z dnia 23 marca 2015 r. w sprawie przyjęcia sprawozdania z wykonania budżetu gminy Lidzbark za 2014 rok (Dz.Urz. Woj. Warmińsko-Mazurskiego z 2015 r., poz. 1476); Zarządzenie Nr 30/16 Burmistrza Lidzbarka z dnia 21 marca 2016 r. w sprawie przyjęcia sprawozdania z wykonania budżetu gminy Lidzbark za 2015 rok (Dz.Urz. Woj. Warmińsko-Mazurskiego z 2016 r., poz. 1810). 


\section{Kształtowanie stawek podatków gruntowych w gminie Lidzbark w latach 2010-2015}

Jednostkom samorządu terytorialnego (gminom) przysługują trzy rodzaje uprawnień w zakresie podatków. Należą do nich: przejmowanie dochodów z przypisanych im prawem podatków, administrowanie określonymi podatkami oraz stanowienie przepisów prawa podatkowego w granicach wyznaczonych ustawą ${ }^{13}$. Jak już wskazano, ostatnie z wymienionych uprawnień realizowane jest w różnym stopniu przez poszczególne samorządy.

Choć podatek od nieruchomości stanowi najważniejsze źródło spośród dochodów własnych gminy Lidzbark, polityka fiskalna samorządu w zakresie kształtowania elementów konstrukcyjnych tego podatku, w granicach przewidzianych ustawą, ograniczała się w zasadzie do określania wysokości stawek podatkowych. Rada gminy nie sięgała po przepis art. 7 ust. 3 ustawy o podatkach i opłatach lokalnych, umożliwiający wprowadzenie, w drodze uchwały, zwolnień przedmiotowych innych niż określone w art. 7 ust. $1^{14}$.

Uchwała określająca wysokość stawek podatku od nieruchomości obowiązujących na obszarze gminy w danym roku podatkowym warunkuje możliwość realizacji tego podatku. Sama ustawa nie stanowi bowiem wystarczającej podstawy do jego poboru ${ }^{15}$. Stawki podatku od nieruchomości, obowiązujące w pierwszym roku badanego okresu przyjęte zostały

13 A. Borodo, Przejmowanie dochodów podatkowych przez gminy, „Prawo Budżetowe Państwa i Samorządu” 2014, nr 3, s. 10-11, DOI: http://dx.doi.org/10.12775/PBPS.2014.026.

14 Rezygnacja z wprowadzenia w drodze uchwały innych zwolnień przedmiotowych niż te, które przewidział ustawodawca, wynikać może z przyjętej polityki podatkowej gminy, akcentującej funkcję fiskalną, tj. dochodową (zob. szerzej: M. Jastrzębska, Polityka budżetowa jednostek samorzq̨du terytorialnego, Gdańsk 2005, s. 74-81). Zauważyć jednak należy, że stosowanie art. 7 ust. 3 u.p.o.l. rodzi wiele problemów praktycznych. Może się bowiem zdarzyć, iż rada gminy ustanowi wprawdzie zwolnienie o charakterze przedmiotowym, jednakże „doprecyzuje” cechy określające ten przedmiot, wskazując na konkretne podmioty. W związku z tym może pojawić się zarzut zastosowania przez organ stanowiący gminy zwolnienia o mieszanym, przedmiotowo-podmiotowym charakterze, do wprowadzenia którego rada gminy nie posiada umocowania ustawowego, por. J. Wantoch-Rekowski, [w:] W. Morawski (red.), Ustawa o podatkach i opłatach lokalnych. Komentarz, Gdańsk 2009, s. 590.

15 L. Etel, Podatek od nieruchomości, [w:] C. Kosikowski, E. Ruśkowski (red.), Finanse publiczne i prawo finansowe, Warszawa 2008, s. 587. 
uchwałą nr XXXVII/271/09 Rady Miejskiej w Lidzbarku z dnia 26 listopada 2009 r. w sprawie podatku od nieruchomości ${ }^{16}$ i wynosiły:

1. od gruntów związanych z prowadzeniem działalności gospodarczej, bez względu na sposób zakwalifikowania w ewidencji gruntów i budynków - 0,69 zł od $1 \mathrm{~m}^{2}$ powierzchni;

2. od gruntów pod jeziorami, zajętych na zbiorniki wodne retencyjne lub elektrowni wodnych - 4,04 zł od 1 ha powierzchni;

3. od pozostałych gruntów, w tym gruntów zajętych na prowadzenie odpłatnej statutowej działalności pożytku publicznego przez organizacje pożytku publicznego - 0,22 zł od $1 \mathrm{~m}^{2}$ powierzchni; wyjątek stanowiły tu grunty zajęte na tereny mieszkaniowe oznaczone w ewidencji gruntów i budynków symbolem (B) oraz zurbanizowane tereny niezabudowane (Bp) - stawka w tym przypadku wynosiła 0,17 zł od $1 \mathrm{~m}^{2}$ powierzchni;

4. od budynków (bądź ich części):

a) mieszkalnych - 0,62 zł od $1 \mathrm{~m}^{2}$ powierzchni użytkowej;

b) związanych z prowadzeniem działalności gospodarczej oraz od budynków mieszkalnych lub ich części zajętych na prowadzenie działalności gospodarczej - 17,46 zł od $1 \mathrm{~m}^{2}$ powierzchni użytkowej;

c) zajętych na prowadzenie działalności gospodarczej w zakresie obrotu kwalifikowanym materiałem siewnym - 9,57 zł od $1 \mathrm{~m}^{2}$ powierzchni użytkowej;

d) zajętych na prowadzenie działalności gospodarczej w zakresie udzielania świadczeń zdrowotnych $-4,16$ zł od $1 \mathrm{~m}^{2}$ powierzchni użytkowej;

e) pozostałych, w tym zajętych na prowadzenie odpłatnej statutowej działalności pożytku publicznego przez organizacje pożytku publicznego - 5,52 zł od $1 \mathrm{~m}^{2}$ powierzchni użytkowej;

5. od budowli - 2\% ich wartości, ustalonej zgodnie z zasadami określonymi w ustawie o podatkach i opłatach lokalnych.

16 Dz.Urz. Woj. Warmińsko-Mazurskiego z 2010 r. Nr 2, poz. 54. 
W kolejnych latach stawki podatku od nieruchomości ulegały nieznacznym zmianom, wykazując jednak systematycznie tendencję wzrostową. Ich wysokość w latach 2011-2015 ilustruje tabela 2.

Tabela 2. Stawki podatku od nieruchomości w gminie Lidzbark w latach 2011-2015.

\begin{tabular}{|c|c|c|c|c|c|}
\hline Przedmiot opodatkowania & 2011 & 2012 & 2013 & 2014 & 2015 \\
\hline $\begin{array}{l}\text { Grunty związane z prowadze- } \\
\text { niem działalności gospodarczej, } \\
\text { bez względu na sposób zakwali- } \\
\text { fikowania w ewidencji gruntów } \\
\text { i budynków }\end{array}$ & $\begin{array}{l}0,71 \mathrm{zł} \mathrm{od} \\
1 \mathrm{~m}^{2} \text { pow. }\end{array}$ & $\begin{array}{l}0,74 \mathrm{zł} \mathrm{od} \\
1 \mathrm{~m}^{2} \text { pow. }\end{array}$ & $\begin{array}{l}0,77 \mathrm{zł} \mathrm{od} \\
1 \mathrm{~m}^{2} \text { pow. }\end{array}$ & $\begin{array}{l}0,78 \text { zł od } \\
1 \mathrm{~m}^{2} \text { pow. }\end{array}$ & $\begin{array}{l}0,78 \mathrm{zł} \mathrm{od} \\
1 \mathrm{~m}^{2} \text { pow. }\end{array}$ \\
\hline $\begin{array}{l}\text { Grunty pod jeziorami zajętymi na } \\
\text { zbiorniki wodne retencyjne lub } \\
\text { elektrowni wodnych }\end{array}$ & $\begin{array}{l}4,15 \text { zł od } \\
1 \text { ha pow. }\end{array}$ & $\begin{array}{l}4,33 \text { zł od } \\
1 \text { ha pow. }\end{array}$ & $\begin{array}{l}4,51 \text { zł od } \\
1 \text { ha pow. }\end{array}$ & $\begin{array}{l}4,56 \text { zł od } \\
1 \text { ha pow. }\end{array}$ & $\begin{array}{l}4,56 \mathrm{zł} \mathrm{od} \\
1 \text { ha pow. }\end{array}$ \\
\hline $\begin{array}{l}\text { Pozostałe grunty, w tym grunty } \\
\text { zajęte na prowadzenie odpłatnej } \\
\text { statutowej działalności pożytku } \\
\text { publicznego przez organizacje } \\
\text { pożytku publicznego, z wyjąt- } \\
\text { kiem gruntów zajętych na tereny } \\
\text { mieszkaniowe oznaczone symbo- } \\
\text { lem (B) oraz zurbanizowane } \\
\text { tereny niezabudowane (Bp) - } \\
\text { stawka w tym przypadku wynosi } \\
0,17 \text { zł od } 1 \mathrm{~m}^{2} \text { powierzchni }\end{array}$ & $\begin{array}{l}0,23 \text { zł od } \\
1 \mathrm{~m}^{2} \text { pow. }\end{array}$ & $\begin{array}{l}0,24 \mathrm{zł} \mathrm{od} \\
1 \mathrm{~m}^{2} \text { pow. }\end{array}$ & $\begin{array}{l}0,25 \mathrm{zł} \mathrm{od} \\
1 \mathrm{~m}^{2} \text { pow. }\end{array}$ & $\begin{array}{l}0,26 \text { zł od } \\
1 \mathrm{~m}^{2} \text { pow. }\end{array}$ & $\begin{array}{l}0,26 \mathrm{zł} \mathrm{od} \\
1 \mathrm{~m}^{2} \text { pow. }\end{array}$ \\
\hline Budynki mieszkalne & $\begin{array}{l}0,64 \text { zł od } \\
1 \mathrm{~m}^{2} \text { pow. } \\
\text { użytkowej }\end{array}$ & $\begin{array}{l}0,68 \text { zł od } \\
1 \mathrm{~m}^{2} \text { pow. } \\
\text { użytkowej }\end{array}$ & $\begin{array}{l}0,70 \text { zł od } \\
1 \mathrm{~m}^{2} \text { pow. } \\
\text { użytkowej }\end{array}$ & $\begin{array}{l}0,72 \text { zł od } \\
1 \mathrm{~m}^{2} \text { pow. } \\
\text { użytkowej }\end{array}$ & $\begin{array}{l}0,72 \text { zł od } \\
1 \mathrm{~m}^{2} \text { pow. } \\
\text { użytkowej }\end{array}$ \\
\hline $\begin{array}{l}\text { Budynki związane z prowadze- } \\
\text { niem działalności gospodarczej } \\
\text { oraz budynki mieszkalne lub ich } \\
\text { części zajęte na prowadzenie } \\
\text { działalności gospodarczej }\end{array}$ & $\begin{array}{l}17,92 \text { zł od } \\
1 \mathrm{~m}^{2} \text { pow. } \\
\text { użytkowej }\end{array}$ & $\begin{array}{l}18,68 \text { zł od } \\
1 \mathrm{~m}^{2} \text { pow. } \\
\text { użytkowej }\end{array}$ & $\begin{array}{l}19,42 \text { zł od } \\
1 \mathrm{~m}^{2} \text { pow. } \\
\text { użytkowej }\end{array}$ & $\begin{array}{l}19,88 \text { zł od } \\
1 \mathrm{~m}^{2} \text { pow. } \\
\text { użytkowej }\end{array}$ & $\begin{array}{l}19,88 \text { zł od } \\
1 \mathrm{~m}^{2} \text { pow. } \\
\text { użytkowej }\end{array}$ \\
\hline $\begin{array}{l}\text { Budynki zajęte na prowadzenie } \\
\text { działalności gospodarczej w zakre- } \\
\text { sie obrotu kwalifikowanym mate- } \\
\text { riałem siewnym }\end{array}$ & $\begin{array}{l}9,82 \text { zł od } \\
1 \mathrm{~m}^{2} \text { pow. } \\
\text { użytkowej }\end{array}$ & $\begin{array}{l}10,24 \text { zł od } \\
1 \mathrm{~m}^{2} \text { pow. } \\
\text { użytkowej }\end{array}$ & $\begin{array}{l}10,65 \text { zł od } \\
1 \mathrm{~m}^{2} \text { pow. } \\
\text { użytkowej }\end{array}$ & $\begin{array}{l}10,75 \mathrm{zł} \mathrm{od} \\
1 \mathrm{~m}^{2} \text { pow. } \\
\text { użytkowej }\end{array}$ & $\begin{array}{l}10,75 \mathrm{zł} \mathrm{od} \\
1 \mathrm{~m}^{2} \text { pow. } \\
\text { użytkowej }\end{array}$ \\
\hline $\begin{array}{l}\text { Budynki związane z prowadze- } \\
\text { niem działalności gospodarczej } \\
\text { w zakresie udzielania świadczeń } \\
\text { zdrowotnych, zajęte przez pod- } \\
\text { mioty udzielające tych świadczeń }\end{array}$ & $\begin{array}{l}4,27 \text { zł od } \\
1 \mathrm{~m}^{2} \text { pow. } \\
\text { użytkowej }\end{array}$ & $\begin{array}{l}4,45 \mathrm{zł} \text { od } \\
1 \mathrm{~m}^{2} \text { pow. } \\
\text { użytkowej }\end{array}$ & $\begin{array}{l}4,63 \text { zł od } \\
1 \mathrm{~m}^{2} \text { pow. } \\
\text { użytkowej }\end{array}$ & $\begin{array}{l}4,68 \text { zł od } \\
1 \mathrm{~m}^{2} \text { pow. } \\
\text { użytkowej }\end{array}$ & $\begin{array}{l}4,68 \text { zł od } \\
1 \mathrm{~m}^{2} \text { pow. } \\
\text { użytkowej }\end{array}$ \\
\hline
\end{tabular}




\begin{tabular}{|l|c|c|c|c|c|}
\hline $\begin{array}{l}\text { Pozostałe budynki, w tym zajęte } \\
\text { na prowadzenie odpłatnej statuto- } \\
\text { wej działalności pożytku publicz- } \\
\text { nego przez organizacje pożytku } \\
\text { publicznego }\end{array}$ & $\begin{array}{c}5,66 \mathrm{zł} \text { od } \\
1 \mathrm{~m}^{2} \text { pow. } \\
\text { użytkowej }\end{array}$ & $\begin{array}{c}5,90 \mathrm{zł} \mathrm{od} \\
1 \mathrm{~m}^{2} \text { pow. } \\
\text { użytkowej }\end{array}$ & $\begin{array}{c}6,14 \mathrm{zł} \mathrm{od} \\
1 \mathrm{~m}^{2} \text { pow. } \\
\text { użytkowej }\end{array}$ & $\begin{array}{c}6,28 \mathrm{zł} \text { od } \\
1 \mathrm{~m}^{2} \text { pow. } \\
\text { użytkowej }\end{array}$ & $\begin{array}{c}6,28 \mathrm{zł} \mathrm{od} \\
1 \mathrm{~m}^{2} \text { pow. } \\
\text { użytkowej }\end{array}$ \\
\hline Budowle & $\begin{array}{c}2 \% \\
\text { wartości }\end{array}$ & $\begin{array}{c}2 \% \\
\text { wartości }\end{array}$ & $\begin{array}{c}2 \% \\
\text { wartości }\end{array}$ & $\begin{array}{r}2 \% \\
\text { wartości }\end{array}$ & $\begin{array}{c}2 \% \\
\text { wartości }\end{array}$ \\
\hline
\end{tabular}

Źródło: Opracowanie własne na podstawie uchwał Rady Miejskiej w Lidzbarku w sprawie podatku od nieruchomości z lat 2010-2013 ${ }^{17}$.

Drugim co do ważności podatkiem lokalnym z punktu widzenia interesów finansowych gminy Lidzbark jest podatek rolny, regulowany przepisami ustawy z 1984 r. ${ }^{18} \mathrm{~W}$ latach 2010-2015 na terenie gminy Lidzbark stosowano ustawowe zwolnienia $\mathrm{z}$ tytułu nabycia gruntów przeznaczonych na utworzenie nowego gospodarstwa rolnego lub powiększenie już istniejącego do powierzchni nieprzekraczającej 100 ha:

a) będących przedmiotem prawa własności lub prawa użytkowania wieczystego, nabytych w drodze umowy sprzedaży,

b) będących przedmiotem umowy o oddanie gruntów w użytkowanie wieczyste,

c) wchodzących w skład Zasobu Własności Rolnej Skarbu Państwa, objętych w trwałe zagospodarowanie

oraz ulgę inwestycyjną z tytułu wydatków poniesionych na:

17 Uchwała Nr XXXVII/271/09 Rady Miejskiej w Lidzbarku z dnia 26 listopada 2009 r. w sprawie podatku od nieruchomości (Dz.Urz. Woj. Warmińsko-Mazurskiego z 2010 r. $\mathrm{Nr}$ 2, poz. 54); Uchwała Nr XLIX/358/10 Rady Miejskiej w Lidzbarku z dnia 4 listopada 2010 r. w sprawie podatku od nieruchomości (Dz.Urz. Woj. WarmińskoMazurskiego z 2010 r. Nr 211, poz. 2850); Uchwała Nr XII/84/11 Rady Miejskiej w Lidzbarku z dnia 27 października 2011 r. w sprawie podatku od nieruchomości (Dz.Urz. Woj. Warmińsko-Mazurskiego z 2011 r. Nr 191, poz. 2767); Uchwała Nr XXII/188/12 Rady Miejskiej w Lidzbarku z dnia 29 listopada 2012 r. w sprawie podatku od nieruchomości, (Dz.Urz. Woj. Warmińsko-Mazurskiego z 2012 r., poz. 3375); Uchwała Nr XXXII/293/13 Rady Miejskiej w Lidzbarku z dnia 28 października 2013 r. w sprawie podatku od nieruchomości, (Dz.Urz. Woj. Warmińsko-Mazurskiego z 2013 r., poz. 3127) - uchwała ta obowiązywała także w roku podatkowym 2015.

18 Ustawa z dnia 15 listopada 1984 r. o podatku rolnym (tekst jedn. Dz.U. z 2017 r., poz. 1892). 
a) budowę lub modernizację budynków inwentarskich służących do chowu, hodowli i utrzymywania zwierząt gospodarskich oraz obiektów służących ochronie środowiska,

b) zakup i zainstalowanie: deszczowni, urządzeń melioracyjnych i urządzeń zaopatrzenia gospodarstwa w wodę, urządzeń do wykorzystywania na cele produkcyjne naturalnych źródeł energii (wiatru, biogazu, słońca, spadku wód).

Ulga inwestycyjna przyznawana jest po zakończeniu inwestycji i polega na odliczeniu od kwoty należnego podatku rolnego od gruntów położonych na terenie gminy Lidzbark 25\% udokumentowanych rachunkami nakładów inwestycyjnych. Ulga z tytułu tej samej inwestycji nie może być stosowana dłużej niż przez 15 lat ${ }^{19}$.

Ceny skupu żyta przyjęte dla ustalenia stawek podatku rolnego obowiązujących w latach 2010-2011 były zgodne ze średnimi cenami skupu żyta, ogłoszonymi w komunikacie Prezesa GUS ${ }^{20}$. W latach 2012-2015 Rada Miejska obniżała średnią cenę skupu żyta ${ }^{21}$. W 2012 r. średnia cena

19 Zob. Biuletyn Informacji Publicznej Urzędu Miasta i Gminy Lidzbark, http://bip.umig.lidzbark.pl/sprawa-do-zalatwienia/421/podatek-rolny-od-osob-prawnych, (dostęp: 10.11.2017 r.). Należy zauważyć, że ulga ta w obecnym kształcie nie stanowi istotnego instrumentu wsparcia inwestycji. Zdarza się, że podatnicy nie są w nawet w stanie odliczyć pełnej kwoty przysługującej im ulgi, jako że kwoty należnego podatku rolnego są zbyt niskie w stosunku do bardzo kosztownych inwestycji, zob. M. Miszczuk, System podatków i opłat samorzq̨dowych w Polsce, Warszawa 2009, s. 78. Zgodnie z komunikatami Prezesa GUS średnia cena skupu $1 \mathrm{q}$ żyta będąca podstawą do ustalenia podatku rolnego wynosiła: w 2010 r. - 34,10 zł (M.P. z 2009 r. Nr 68, poz. 886), w 2011 r. - 37,64 zł (M.P. z 2010 r. Nr 76, poz. 960), w 2012 r. - 74,18 zł (M.P. z 2011 r. Nr 95, poz. 969), w 2013 r. - 75,86 zł (M.P. z 2012 r., poz. 787), w 2014 r. 69,28 zł (M.P. z 2013 r., poz. 814), w 2015 r. - 61,37 zł (M.P. z 2014 r., poz. 935).

21 Uchwała Nr XII/86/11 Rady Miejskiej w Lidzbarku z dnia 27 października 2011 r. w sprawie obniżenia średniej ceny skupu 1 q żyta jako podstawy do obliczenia podatku rolnego w Gminie Lidzbark, (Dz.Urz. Woj. Warmińsko-Mazurskiego z 2011 r. Nr 191, poz. 2769); Uchwała Nr XXII/190/12 Rady Miejskiej w Lidzbarku z dnia 29 listopada 2012 r. w sprawie obniżenia średniej ceny skupu 1 q żyta jako podstawy do obliczenia podatku rolnego w Gminie Lidzbark (Dz.Urz. Woj. Warmińsko-Mazurskiego z 2012 r., poz. 3377); Uchwała Nr XXXIII/298/13 Rady Miejskiej w Lidzbarku z dnia 25 listopada 2013 r. w sprawie obniżenia średniej ceny skupu 1 q żyta jako podstawy do obliczenia podatku rolnego w Gminie Lidzbark (Dz.Urz. Woj. WarmińskoMazurskiego z 2013 r., poz. 3461); Uchwała Nr XLII/376/14 Rady Miejskiej w Lidzbarku z dnia 30 października 2014 r. w sprawie średniej ceny skupu żyta jako podsta- 
skupu 1 q żyta została obniżona do 45 zł, w 2013 r. - do 47 zł, a w roku 2015 do 53 zł. Zależność między średnią ceną skupu 1 q żyta wynikającą z komunikatu Prezesa GUS a średnią ceną skupu żyta po zastosowaniu obniżki, o której mowa w art. 6 ust. 3 ustawy o podatku rolnym, przedstawia wykres 1.

Wykres 1. Średnia cena skupu żyta służąca do ustalania stawek podatku rolnego w gminie Lidzbark w latach 2010-2015 w porównaniu z cenami średnimi wynikającymi z komunikatów Prezesa GUS.

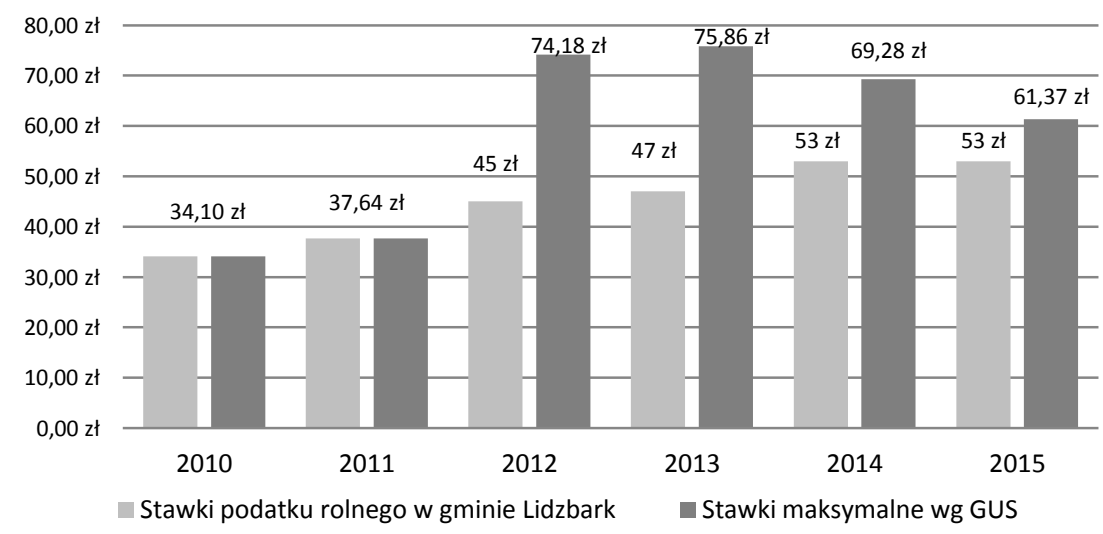

Źródło: Opracowanie własne na podstawie komunikatów Prezesa GUS oraz uchwał Rady Miejskiej w Lidzbarku.

W 2012 r. stawka maksymalna podatku wzrosła o 49,26\%, w gminie Lidzbark przyjęto zaś stawkę wyższą o 16\% w stosunku do roku 2011. Podobna różnica między stawką maksymalną a stawką przyjętą w uchwale Rady Miejskiej wystąpiła w 2013 r. W kolejnych latach wysokości uchwalanych stawek wykazywały różnicę rzędu kilkunastu zł względem stawek maksymalnych.

Na trzecim miejscu wśród podatków lokalnych, jeśli chodzi o wysokość uzyskiwanych wpływów budżetowych, plasuje się podatek leśny,

wy do obliczenia podatku rolnego w Gminie Lidzbark (Dz.Urz. Woj. WarmińskoMazurskiego z 2014 r., poz. 3840). 
regulowany przepisami ustawy z $2002 \mathrm{r} .^{22} \mathrm{Na}$ przestrzeni lat 2010-2015 gmina Lidzbark nie kształtowała stawek podatku leśnego w granicach przysługującego jej władztwa podatkowego, lecz stosowała stawki maksymalne, obliczone w oparciu o średnią cenę sprzedaży drewna ogłaszaną przez Prezesa GUS ${ }^{23}$. Ponieważ lasy zajmują prawie 50\% powierzchni gminy, zabieg ten, jak się wydaje, miał na celu maksymalizację dochodów podatkowych z tego źródła.

\section{Analiza dochodów budżetowych z podatków gruntowych w gminie Lidzbark w latach 2010-2015}

\subsection{Podatek od nieruchomości}

Podatek od nieruchomości stanowił najważniejsze źródło dochodów własnych gminy Lidzbark w badanym okresie. Wysokość wpływów z tego tytułu wahała się od 43,41\% ogółu dochodów własnych w 2010 r. do 50,44\% w roku 2015. Wpływy z podatku od nieruchomości, przedstawione na wykresie 2, wykazywały systematyczną tendencję wzrostową, do czego przyczynił się z pewnością coroczny wzrost stawek podatku, przedstawiony w poprzednim punkcie.

22 Ustawa z dnia 30 października 2002 r. o podatku leśnym (tekst jedn. Dz.U. z 2017 r., poz. 1821).

23 Zgodnie z komunikatami Prezesa GUS średnia cena sprzedaży drewna uzyskana przez nadleśnictwa za pierwsze trzy kwartały roku poprzedzającego rok podatkowy i stosowana do obliczenia wysokości stawki podatku wynosiła: w 2010 r. - 136,54 zł (M.P. z 2009 r. Nr 69, poz. 896), w 2011 r. - 154,65 zł (M.P. z 2010 r. Nr 78, poz. 970), w 2012 r. - 186,68 zł (M.P. z 2011 r. Nr 95, poz. 970), w 2013 r. - 186,42 zł (M.P. z 2012 r., poz. 788), w 2014 r. - 171,05 zł (M.P. z 2013 r., poz. 828), w 2015 r. 188,85 zł (M.P. z 2014 r., poz. 955). 
Daria Zaborek, Krzysztof Czarnecki

Wykres 2. Wpływy z podatku od nieruchomości w gminie Lidzbark w latach 2010-2015.

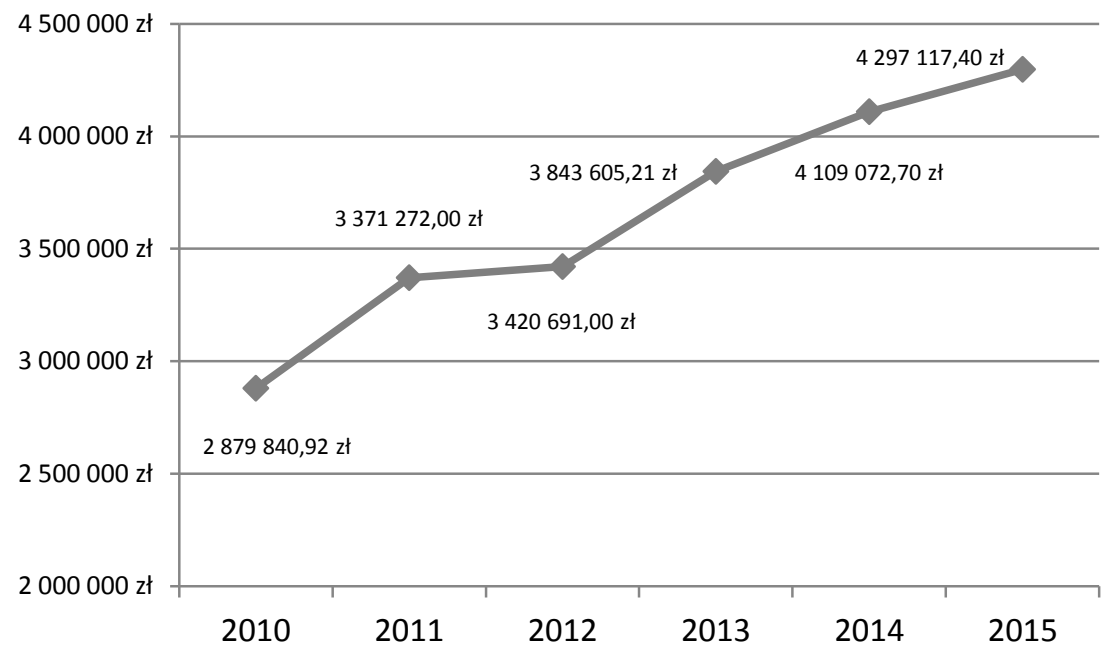

Źródło: Opracowanie własne na podstawie sprawozdań z wykonania budżetu gminy Lidzbark.

Podkreślić należy, że dochody z podatku od nieruchomości w latach 2010-2015 każdego roku zostały wykonane powyżej 100\% wielkości planowanej. W 2010 r. dochody zostały wykonane na poziomie 103,5\% planu, w 2011 r. było to 117,5\%, w 2012 r. - 105,9\%, w 2013 r. - 111,6\%, w 2014 r. $-115,7 \%$, natomiast w roku $2015-123 \%$.

Udział podatku od nieruchomości w dochodach z podatków lokalnych zawierał się w przedziale od $71,14 \%$ do $74,96 \%$. Najniższy udział występował w roku 2010, najwyższy zaś - w 2015. W 2011 r. można zaobserwować znaczący wzrost udziału podatku od nieruchomości, bliski maksymalnemu zanotowanemu w badanym okresie. Wartości te przedstawia wykres 3 . 
Wykres 3. Udział podatku od nieruchomości w dochodach z podatków lokalnych w gminie Lidzbark w latach 2010-2015.

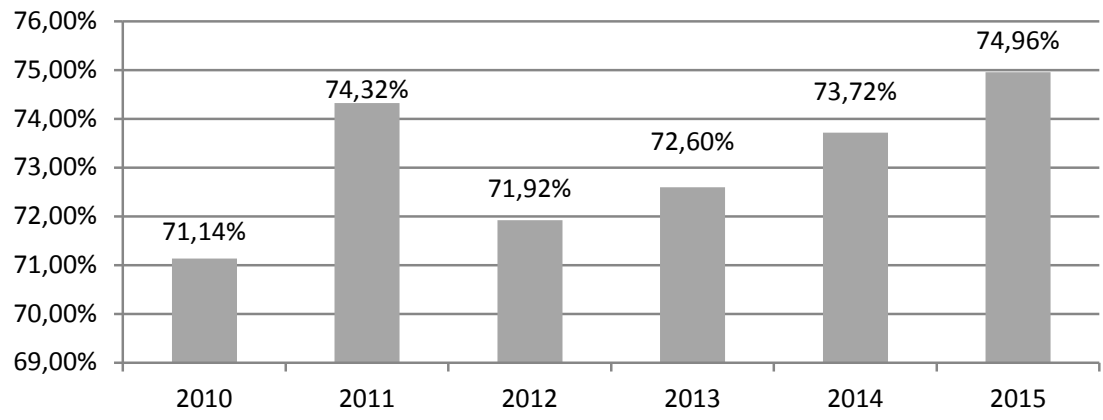

Źródło: Opracowanie własne na podstawie sprawozdań z wykonania budżetu gminy Lidzbark.

Udział podatku od nieruchomości na tle ogółu dochodów własnych gminy także wykazywał tendencję wzrostową. Przedstawia to wykres 4.

Wykres 4. Udział podatku od nieruchomości w dochodach własnych gminy Lidzbark w latach 2010-2015.

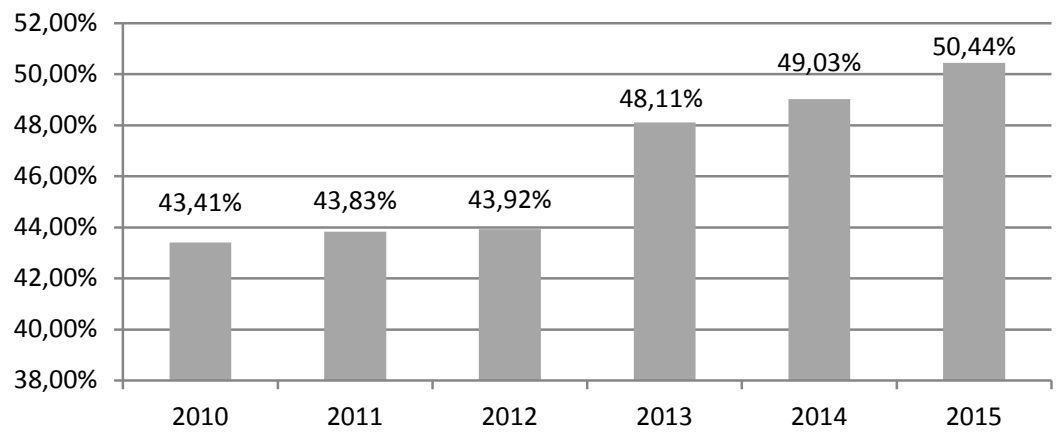

Źródło: Opracowanie własne na podstawie sprawozdań z wykonania budżetu gminy Lidzbark.

Na wykresie 5 przedstawiony został udział podatku od nieruchomości na tle ogółu dochodów budżetowych gminy w okresie 2010-2015, a więc przy uwzględnieniu otrzymanych kwot subwencji ogólnej i dotacji celowych. W drugiej połowie analizowanego okresu sięgał on ok. 10\% dochodów budżetowych, był zatem ważnym źródłem dochodowym w ujęciu globalnym. 
Wykres 5. Udział podatku od nieruchomości w ogólnej kwocie dochodów gminy Lidzbark w latach 2010-2015.

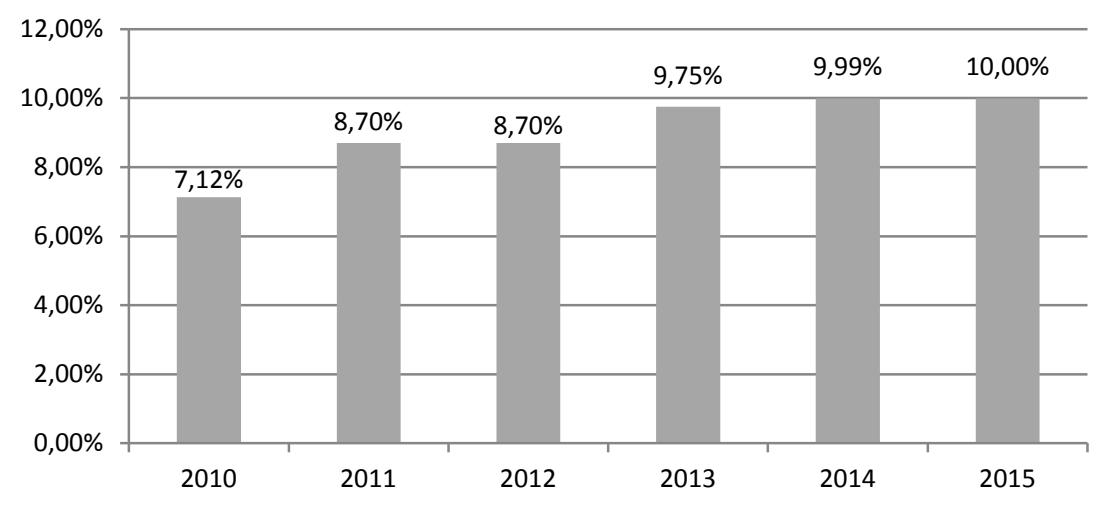

Źródło: Opracowanie własne na podstawie sprawozdań z wykonania budżetu gminy Lidzbark.

\subsection{Podatek rolny}

Wpływy z podatku rolnego na przestrzeni omawianych sześciu lat charakteryzowały się znaczącym wzrostem. W roku 2010 dochody budżetowe z tego tytułu wyniosły ok. 300000 zł, zaś na końcu badanego okresu, w latach 2014-2015, przekraczały kwotę 470000 zł. Zanotowany wzrost wpływów był wynikiem sukcesywnego wzrostu stawek. Podobnie jak w przypadku podatku od nieruchomości, dochody z podatku rolnego każdego roku zostały wykonane powyżej 100\% wielkości planowanych. 
Wykres 6. Wpływy z podatku rolnego w gminie Lidzbark w latach 2010-2015.

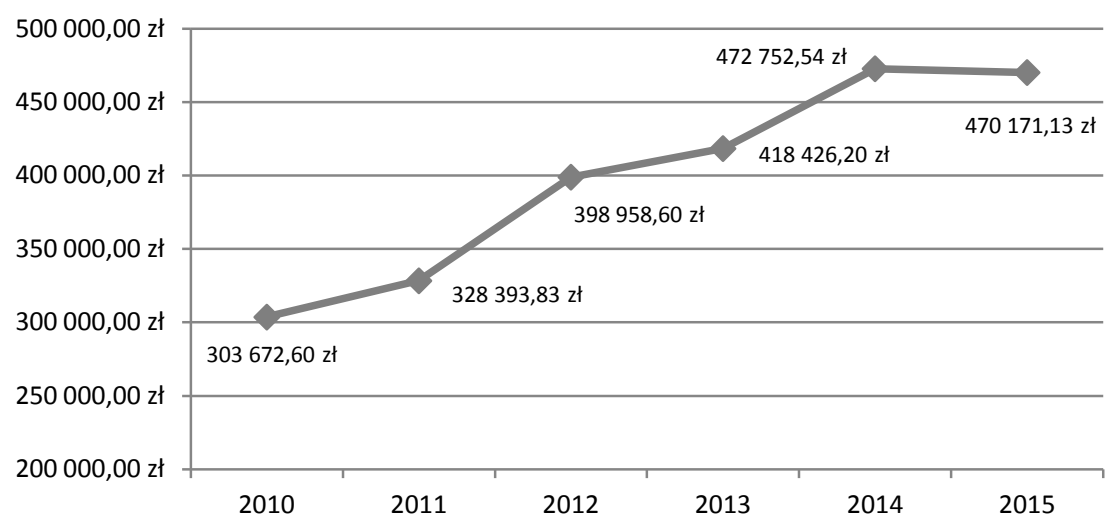

Źródło: Opracowanie własne na podstawie sprawozdań z wykonania budżetu gminy Lidzbark.

Jak pokazuje poniższy wykres, udział podatku rolnego w dochodach podatkowych gminy Lidzbark nie wykazywał dużego zróżnicowania. Najniższy, na poziomie 7,24\% wystąpił w 2011 r., najwyższy zaś w roku $2014-8,48 \%$.

Wykres 7. Udział podatku rolnego w dochodach z podatków lokalnych w gminie Lidzbark w latach 2010-2015.

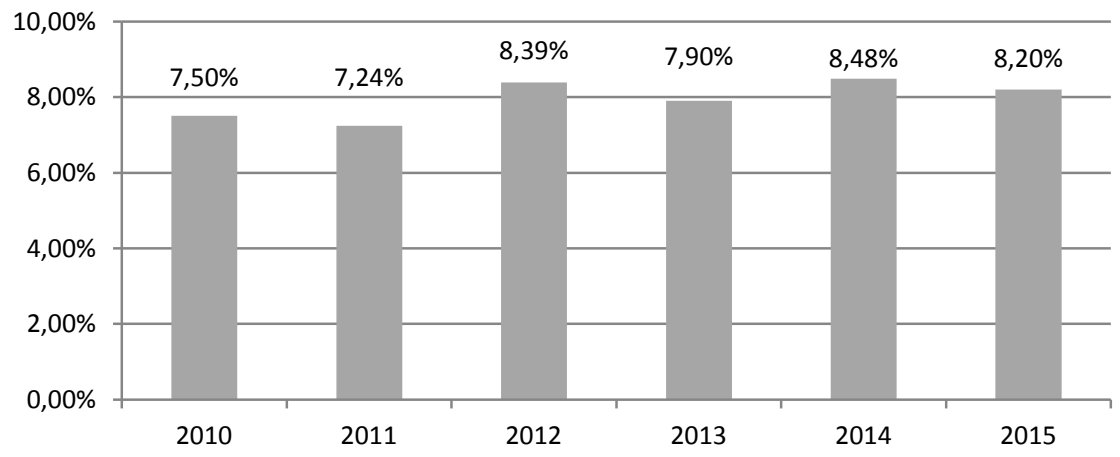

Źródło: Opracowanie własne na podstawie sprawozdań z wykonania budżetu gminy Lidzbark. 
Udział podatku rolnego na tle ogółu dochodów własnych gminy Lidzbark był niewielki i wahał się w granicach 4,58-5,64\%. Wykazywał jednakże tendencję wzrostową.

Wykres 8. Udział podatku rolnego w dochodach własnych gminy Lidzbark w latach 2010_ 2015.

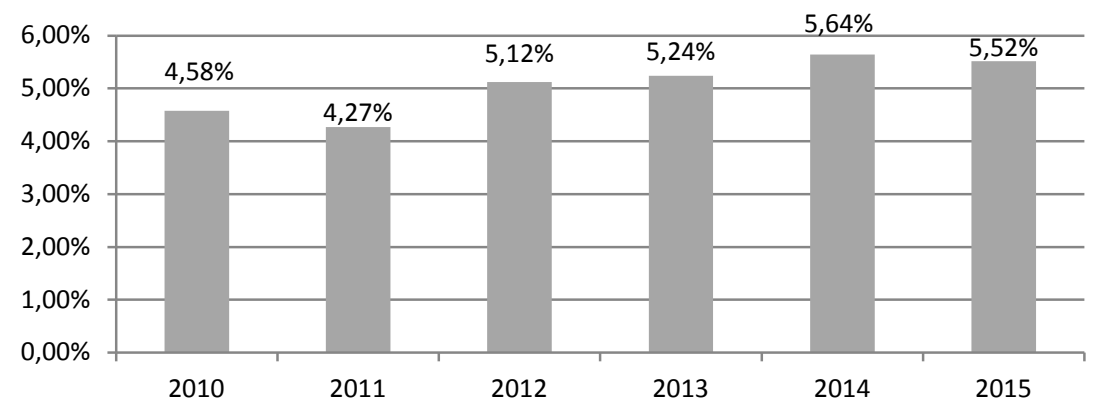

Źródło: Opracowanie własne na podstawie sprawozdań z wykonania budżetu gminy Lidzbark.

Analiza znaczenia wpływów z podatku rolnego na tle całokształtu dochodów gminy Lidzbark (dochody własne, subwencja ogólna, dotacje celowe) wskazuje, że był on źródłem o niewielkim znaczeniu dla budżetu.

Wykres 9. Udział podatku rolnego w ogóle dochodów gminy Lidzbark w latach 2010-2015.

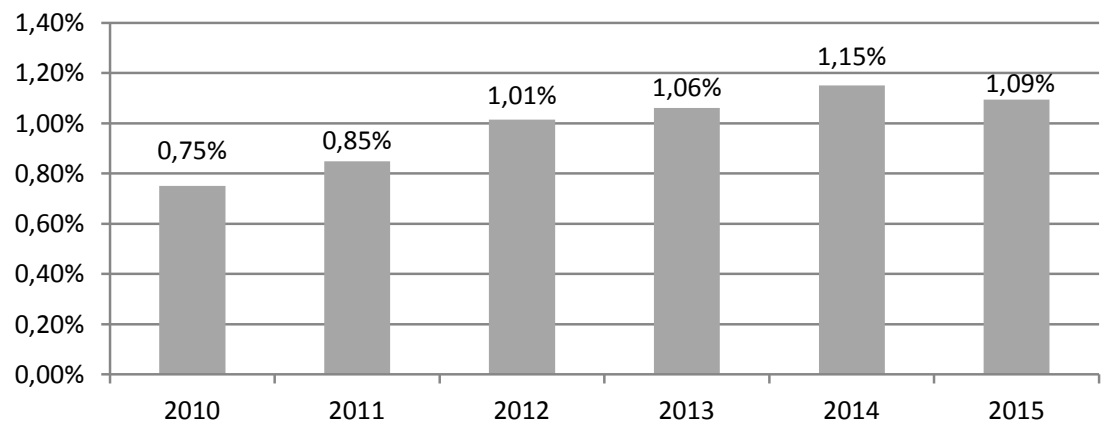

Źródło: Opracowanie własne na podstawie sprawozdań z wykonania budżetu gminy Lidzbark. 


\subsection{Podatek leśny}

Dochody budżetowe gminy Lidzbark z tytułu podatku leśnego przedstawia wykres 10 . Wykazywały one ścisłe powiązanie z wysokością stawki obowiązującej w danym roku, uzależnionej od średniej ceny sprzedaży $1 \mathrm{~m}^{3}$ drewna ogłoszonej w komunikacie Prezesa GUS. Charakteryzował je wzrost w latach 2010-2012, wynikający z rosnącej ceny sprzedaży drewna. W roku 2014 nastąpił niewielki spadek, jednakże na koniec badanego okresu dochody z tytułu podatku leśnego osiągnęły najwyższą wartość w analizowanym przedziale czasowym.

Wykres 10. Wpływy z podatku leśnego w gminie Lidzbark w latach 2010-2015.

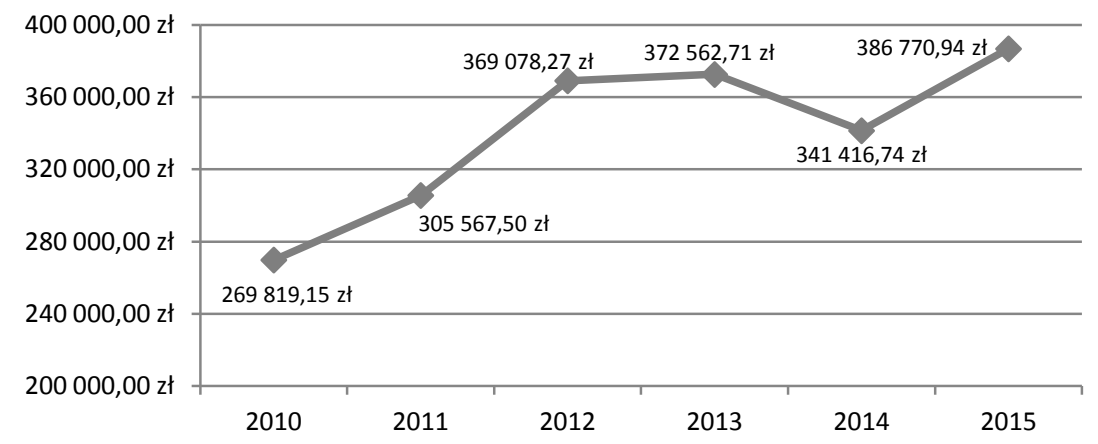

Źródło: Opracowanie własne na podstawie sprawozdań z wykonania budżetu gminy Lidzbark.

W przypadku podatku leśnego dochody zostały wykonane powyżej $100 \%$ wielkości planowanych, z wyjątkiem roku 2014, kiedy to wykonanie osiągnęło 93,4\% wielkości zaplanowanej. Warto zauważyć, że udział podatku leśnego w dochodach z podatków lokalnych kształtował się na poziomie niewiele niższym od podatku rolnego. 
Wykres 11. Udział podatku leśnego w dochodach z podatków lokalnych w gminie Lidzbark w latach 2010-2015.

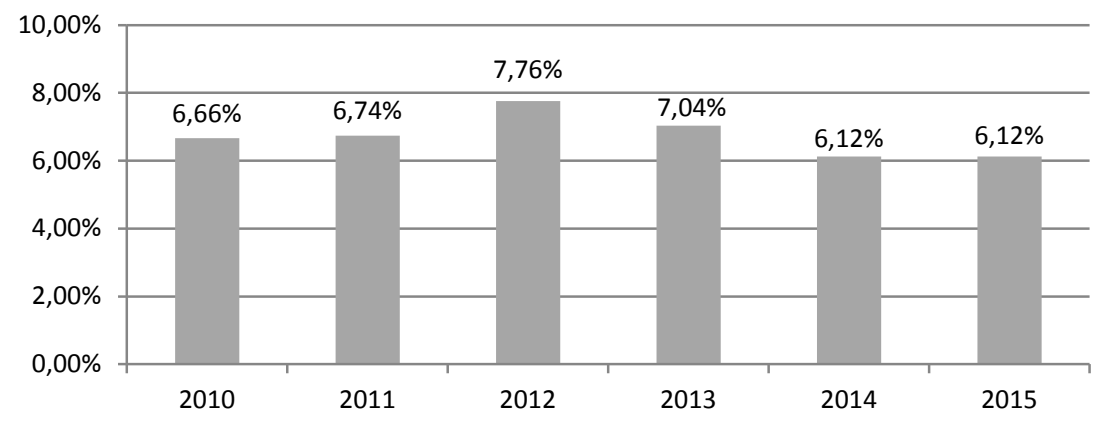

Źródło: Opracowanie własne na podstawie sprawozdań z wykonania budżetu gminy Lidzbark.

Sytuacja wygląda podobnie jak w przypadku podatku rolnego także wtedy, gdy pod uwagę wzięta zostanie wysokość dochodów osiąganych z tytułu podatku leśnego w odniesieniu do ogółu dochodów własnych gminy.

Wykres 12. Udział podatku leśnego w dochodach własnych gminy Lidzbark w latach 2010-2015.

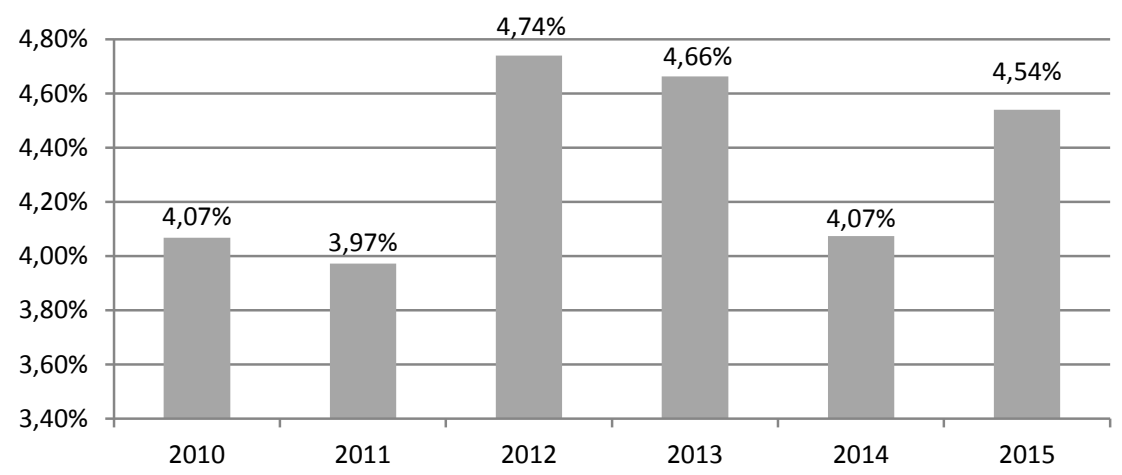

Źródło: Opracowanie własne na podstawie sprawozdań z wykonania budżetu gminy Lidzbark. 
Na tle ogółu dochodów gminy znaczenie podatku leśnego było niewielkie, w badanym okresie wpływy nie przekroczyły poziomu 1\% (mimo, że lasy zajmują ok. 50\% powierzchni gminy Lidzbark).

Wykres 13. Udział podatku leśnego w ogólnej kwocie dochodów gminy Lidzbark w latach 2010-2015.

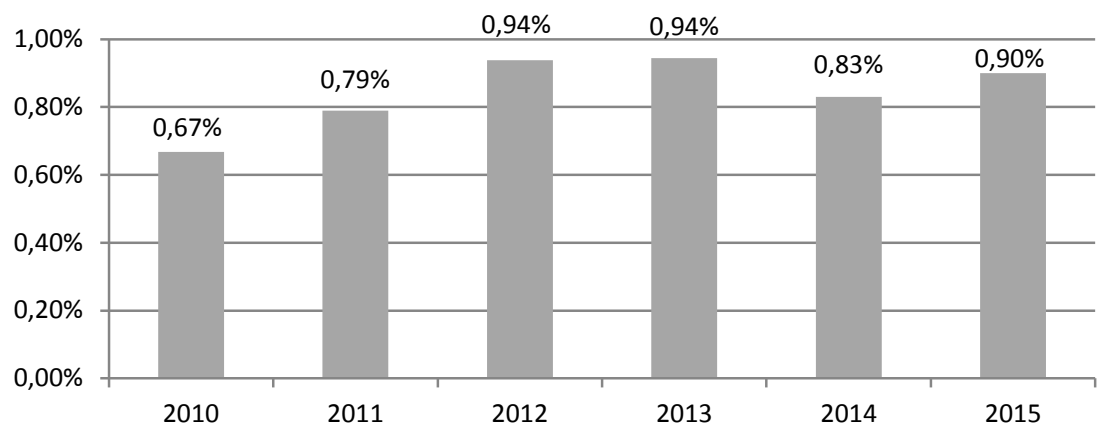

Źródło: Opracowanie własne na podstawie sprawozdań z wykonania budżetu gminy Lidzbark.

\section{Podsumowanie}

Struktura dochodów własnych gminy Lidzbark w latach 2010-2015 nie różniła się znacząco. Najważniejsze źródło dochodów podatkowych stanowił podatek od nieruchomości, na drugim miejscu znajdowały się dochody z majątku gminnego, stanowiące ok. 10\% dochodów własnych. W dalszej kolejności uplasowały się podatek rolny oraz podatek leśny. Wpływy z podatków gruntowych w badanym okresie wykazywały tendencję rosnącą. Wynikało to przede wszystkim ze wzrostu stawek podatkowych.

Udział podatków gruntowych w odniesieniu do ogółu dochodów własnych ilustruje wykres 14 . Jak widać, znaczenie podatków gruntowych wśród dochodów własnych wzrosło w zauważalny sposób, o blisko 8,50\%. Zwiększył się także ich udział w dochodach gminy ogółem. 
Wykres 14. Udział podatków gruntowych w dochodach własnych gminy Lidzbark w latach 2010-2015.

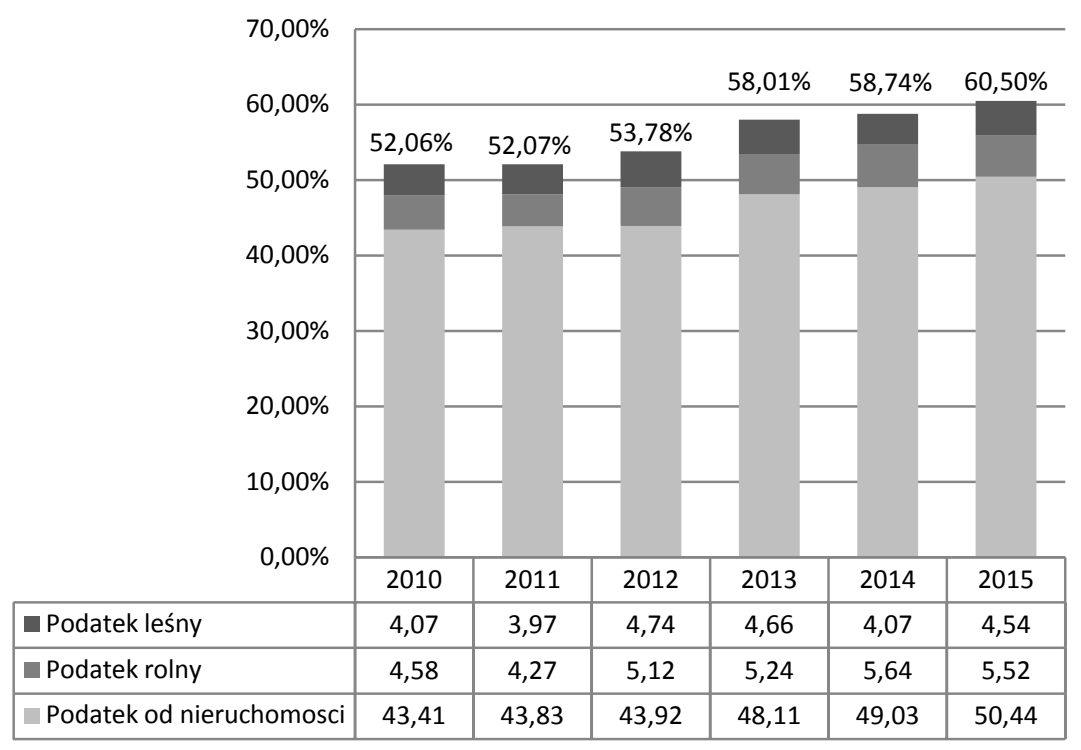

Źródło: Opracowanie własne na podstawie sprawozdań z wykonania budżetu gminy Lidzbark.

Szczegółowe zestawienie dochodów własnych gminy w podziale na poszczególne źródła (w ujęciu procentowym) przedstawia tabela 3.

Tabela 3. Procentowy udział poszczególnych podatków i opłat w strukturze dochodów własnych gminy Lidzbark w latach 2010-2015.

\begin{tabular}{|c|c|c|c|c|c|c|}
\hline \multirow[b]{2}{*}{ Rodzaj dochodu } & \multicolumn{6}{|c|}{$\begin{array}{l}\text { Udział dochodów z danego tytułu na tle ogółu } \\
\text { dochodów własnych w poszczególnych latach (w \%) }\end{array}$} \\
\hline & 2010 & 2011 & 2012 & 2013 & 2014 & 2015 \\
\hline Podatek rolny & 4,58 & 4,27 & 5,12 & 5,24 & 5,64 & 5,52 \\
\hline Podatek leśny & 4,07 & 3,97 & 4,74 & 4,66 & 4,07 & 4,54 \\
\hline Podatek od nieruchomości & 43,41 & 43,83 & 43,92 & 48,11 & 49,03 & 50,44 \\
\hline $\begin{array}{l}\text { Podatek od środków } \\
\text { transportowych }\end{array}$ & 4,38 & 3,99 & 4,13 & 4,18 & 4,00 & 3,90 \\
\hline Podatek od spadków i darowizn & 0,34 & 0,41 & 0,62 & 0,41 & 0,91 & 0,70 \\
\hline Opłata od posiadania psów & 0,03 & 0,02 & 0,04 & 0,18 & 0,15 & 0,19 \\
\hline
\end{tabular}




\begin{tabular}{|l|r|r|r|r|r|r|}
\hline $\begin{array}{l}\text { Podatek dochodowy opłacany } \\
\text { w formie karty podatkowej }\end{array}$ & 0,18 & 0,15 & 0,16 & 0,18 & 0,13 & 0,11 \\
\hline $\begin{array}{l}\text { Podatek od czynności cywilno- } \\
\text { prawnych }\end{array}$ & 4,26 & 2,49 & 2,53 & 3,66 & 2,86 & 2,19 \\
\hline $\begin{array}{l}\text { Rekompensaty z tytułu utraco- } \\
\text { nych dochodów w podatkach } \\
\text { i opłatach lokalnych }\end{array}$ & 5,01 & 2,24 & 0,01 & 0,01 & 0,01 & 0,01 \\
\hline Opłata skarbowa & 0,48 & 0,42 & 0,37 & 0,33 & 0,35 & 0,43 \\
\hline Opłata targowa & 0,87 & 0,75 & 0,70 & 0,64 & 0,61 & 0,73 \\
\hline Opłata miejscowa & 0,17 & 0,19 & 0,21 & 0,17 & 0,18 & 0,11 \\
\hline $\begin{array}{l}\text { Wpływy z innych opłat stanowią- } \\
\text { cych dochód j.s.t. }\end{array}$ & b.d. & b.d. & 1,27 & 2,47 & 2,22 & 2,19 \\
\hline $\begin{array}{l}\text { Opłata za wydanie zezwolenia na } \\
\text { sprzedaż napojów alkoholowych }\end{array}$ & 2,78 & 2,51 & 2,68 & 2,71 & 2,65 & 2,58 \\
\hline Opłata eksploatacyjna & 0,29 & 0,35 & 0,11 & 0,30 & 0,25 & 0,17 \\
\hline Dochody z majątku gminy & 10,48 & 13,74 & 9,19 & 7,95 & 10,40 & 10,88 \\
\hline $\begin{array}{l}\text { Wpływy z opłat i kar za korzysta- } \\
\text { nie ze środowiska }\end{array}$ & b.d. & b.d. & 4,68 & 4,35 & 3,48 & 2,06 \\
\hline $\begin{array}{l}\text { Pozostałe dochody własne (man- } \\
\text { daty, darowizny wpływy z usług } \\
\text { itp.) }\end{array}$ & 18,67 & 20,67 & 19,52 & 14,45 & 13,06 & 13,25 \\
\hline RAZEM & $\mathbf{1 0 0 , 0 0}$ & $\mathbf{1 0 0 , 0 0}$ & $\mathbf{1 0 0 , 0 0}$ & $\mathbf{1 0 0 , 0 0}$ & $\mathbf{1 0 0 , 0 0}$ & $\mathbf{1 0 0 , 0 0}$ \\
\hline
\end{tabular}

Źródło: Opracowanie własne na podstawie sprawozdań z wykonania budżetu gminy Lidzbark.

Z analizy przedstawionych w artykule danych wynika, że podatki gruntowe stanowią łącznie grupę o największym potencjale dochodowym spośród wszystkich źródeł składających się na dochody własne gminy Lidzbark. Postępująca tendencja wzrostowa dochodów z przeanalizowanych trzech źródeł - podatku od nieruchomości, rolnego i leśnego - wskazuje, że władze gminy prowadzą politykę fiskalną cechującą się dążeniem do maksymalizacji uzyskiwanych wpływów. Potwierdzają to uchwały Rady Miejskiej w Lidzbarku, określające stawki podatków lokalnych w poszczególnych latach na poziomie bliskim lub równym stawkom maksymalnym.

Największą rolę spośród wszystkich dochodów własnych odgrywał podatek od nieruchomości. W ostatnim roku analizowanego okresu (2015) wpływy osiągnięte z tego tytułu przewyższyły sumę wpływów z wszelkich pozostałych źródeł dochodu mieszczących się w pojęciu dochodów własnych (50,40\%). 
Choć dochody z podatku rolnego oraz podatku leśnego stanowiły zauważalną pozycję dochodową w obrębie dochodów własnych, ich udział w dochodach gminy ogółem jest niewielki.

W kontekście analizy danych zbiorczych przedstawionych w tabeli 3 można postawić natomiast pytanie o sens poboru takich opłat, jak opłata miejscowa oraz opłata od posiadania psów. Osiągane z nich wpływy stanowią ułamkową część procenta dochodów własnych, generując przy tym określone koszty poboru i administrowania. Próba udzielenia odpowiedzi na to pytanie wykracza jednak poza ramy niniejszego opracowania.

\section{Bibliografia:}

Borodo A., Przejmowanie dochodów podatkowych przez gminy, „Prawo Budżetowe Państwa i Samorządu” 2014, nr 3, DOI: http://dx.doi.org/10.12775/ PBPS.2014.026, s. 9-20.

Borodo A., Samorzq̨ terytorialny. System prawnofinansowy, LexisNexis, Warszawa 2008.

Ciak J., Wąsewicz B., Kataster jako warunek reformy systemu opodatkowania nieruchomości w Polsce, „Prawo Budżetowe Państwa i Samorządu” 2014, nr 4, DOI: http://dx.doi.org/10.12775/PBPS.2014.035, s. 9-29.

Ciak J., Wąsewicz B., Oczekiwany model katastru nieruchomości w Polsce, „Prawo Budżetowe Państwa i Samorządu” 2015, nr 1, DOI: http://dx.doi.org/10.12775/ PBPS.2015.002, s. 27-43.

Cilak M., Instrumenty wspierania rozwoju gospodarczego stosowane przez samorząd terytorialny. Problematyka prawnofinansowa, TNOiK, Toruń 2013.

Etel L., Podatek od nieruchomości, [w:] C. Kosikowski, E. Ruśkowski (red.), Finanse publiczne i prawo finansowe, Wolters Kluwer, Warszawa 2008.

Hanusz A., Niezgoda A., Czerski P., Dochody budżetu jednostek samorzqdu terytorialnego, Wolters Kluwer, Warszawa 2009.

Jastrzębska M., Polityka budżetowa jednostek samorzq̨du terytorialnego, Wydawnictwo Uniwersytetu Gdańskiego, Gdańsk 2005.

Kornberger-Sokołowska E., Decentralizacja finansów publicznych a samodzielność finansowa jednostek samorzqdu terytorialnego, Liber, Warszawa 2001.

Miszczuk M., System podatków i opłat samorzqdowych w Polsce, C.H. Beck, Warszawa 2009. 
Potocki A., Zmiany informacji w ewidencji gruntów i budynków a proces wymiaru podatku od nieruchomości, rolnego i leśnego, „Prawo Budżetowe Państwa i Samorządu” 2016, nr 3, DOI: http://dx.doi.org/10.12775/PBPS.2016.019, s. 145-156.

Wantoch-Rekowski J., [w:] W. Morawski (red.), Ustawa o podatkach i opłatach lokalnych. Komentarz, ODDK, Gdańsk 2009. 